\title{
EDITORIAL
}

\section{Registreren: klik hier}

\author{
Prof. dr. Peter F.A. Mulders
}

Een nieuw abstract nummer voor de najaarsvergadering NVU te Nieuwegein ligt voor $\mathrm{u}$. Vaak zijn de abstracts het resultaat van retrospectief en prospectief onderzoek. Tegenwoordig wordt, behalve uitmuntende zorg, van ons verwacht dat we alles goed registreren. Dit is in het belang van patiënten en dokters. Vele andere partijen zijn in deze registraties geïnteresseerd en passen hun beleid daar op aan. Trajecten en aspecten als 'ontregelde zorg' en 'laat de dokter weer dokteren' komen dan ook naar voren. De administratieve last die gepaard gaat met het bijhouden van elektronische patiëntendossiers is enorm. Meer dan ooit is efficiëntie en optimalisatie gewenst, om te voorkomen dat we uren aan deze gecomputeriseerde registratie moeten besteden. Hadden we dit maar impliciet in ons handelen ingebed zonder dat het ons extra werk opleverde, dan zouden we met een druk op de knop geïnformeerd zijn over hoe we het in de praktijk doen en wat we kunnen verbeteren. Bij het doornemen van de abstracts valt op dat onderzoekers en arts-assistenten - en ook urologen - er toch vaak mee bezig zijn: hun gegevens ophalen, goed registreren en analyseren. De een heeft dit beter ingeregeld dan de ander. Toch zie ik de hier gepresenteerde abstracts als voorbeeld van waar we heen moeten. Registreren van ons handelen, analyseren en interpreteren van de uitkomsten. Niet meer retrospectief of prospectief, maar life op ieder moment van de dag, met een druk op de knop. Ja, we hebben inmiddels alles, zoals dat heet, ' $0-1$ ' in de computer zitten.

Veel leesplezier en een actieve participatie tijdens de wetenschappelijke vergadering van de NVU toegewenst.

Peter F.A. Mulders uroloog

$\triangle$ Prof. dr. P.F.A. Mulders

peter.mulders@radboudumc.nl

Radboudumc, Nijmegen, Nederland

Tijdschrift voor Urologie,

Bohn Stafleu van Loghum, Houten, Nederland 